\title{
Insulin-like growth factor-I-induced DNA synthesis in insulin-secreting cell line RINm5F is associated with phosphorylation of the insulin-like growth factor-I receptor and the insulin receptor substrate-2
}

\author{
Q Zhang, P-O Berggren, A Hansson and M Tally \\ Department of Molecular Medicine, The Endocrine and Diabetes Unit, The Rolf Luft Center for Diabetes Research, Karolinska Institute, S-171 76, \\ Stockholm, Sweden \\ (Requests for offprints should be addressed to Q Zhang)
}

\begin{abstract}
A proliferative effect of insulin-like growth factor-I (IGF-I) was previously shown in pancreatic islets. However, the mechanism under which IGF-I actions are exerted in insulin-secreting cells is not clear. The rat insulinoma cell line, RINm5F, was shown to have both IGF-I receptors and IGF-II/mannose-6-phosphate receptors. IGF-I binding to cell surface receptors stimulated phosphorylation of $97 \mathrm{kDa}$ and $93 \mathrm{kDa}$ subunits of the IGF-I receptor and incorporation of $\left[{ }^{3} \mathrm{H}\right]$ thymidine into RINm5F cells. Both the IGF-I-induced protein phosphorylation and $\left[{ }^{3} \mathrm{H}\right]$ thymidine incorporation were abolished in the presence of the tyrosine kinase inhibitor, genistein. Under basal conditions, IGF-I did not induce
\end{abstract}

insulin release or changes in cytosolic free $\mathrm{Ca}^{2+}$ concentration. Immunoprecipitation of proteins from RINm5F cells, using phosphotyrosine antibodies, followed by western blotting using antibody against IRS- 1 revealed no distinct band of phosphorylated insulin receptor substrate (IRS)-1. Instead, tyrosine-phosphorylated IRS-2 was detected and stimulated by IGF-I when western blotting was performed using antibody against IRS-2. These results indicate that IRS-1 is not likely to be involved in IGF-I signalling in RINm5F cells. Hence, IGF-I stimulated DNA synthesis in RINm5F cells was associated with phosphorylation of IGF-I receptors and IRS-2.

Journal of Endocrinology (1998) 156, 573-581

\section{Introduction}

The insulin-like growth factor-I (IGF-I) receptor, homologous with the insulin receptor, is a heterotetrameric protein, consisting of two $\alpha \beta$ heterodimers. The $\alpha$ subunit is located extracellularly and has a molecular mass of $120-130 \mathrm{kDa}$, whereas the $\beta$ subunit, which is mainly localized intracellularly, is a $93 \mathrm{kDa}$ protein. IGF-I binds to the IGF-I receptor with high affinity. The crossreactions of IGF-II and insulin with the IGF-I receptor are $5-10 \%$ and $0 \cdot 1-1 \%$ respectively (Roth \& Kiess 1994).

The IGF-I receptor belongs to the tyrosine kinase growth factor receptor family. Tyrosine kinase activity and tyrosine phosphorylation of the receptor and intracellular substrates are essential for all actions mediated by the IGF-I receptor (Kato et al. 1994, Li et al. 1994). Binding of IGF-I to its receptor induces autophosphorylation of the receptor and phosphorylation of intracellular substrates, catalysed by the intrinsic tyrosine kinase in the intracellular domain of the receptor $\beta$ subunits (Kato et al. 1994, Jones \& Clemmons 1995). In certain cell types, IGF-I stimulates phosphorylation of two types of $\beta$ subunits of IGF-I receptors with molecular masses of about $97 \mathrm{kDa}$ and $95 \mathrm{kDa}$ (Moxham et al. 1989). The immunological properties and protein microsequencing of the two proteins have revealed the presence of IGF-I/insulin hybrid receptors (Siddle et al. 1994, Kasuya et al. 1993). The hybrid receptors can be formed in vitro using purified heterodimers from insulin receptors and IGF-I receptors (Treadway et al. 1989). Several intracellular proteins have been found to be phosphorylated after activation of IGF-I receptors (Oh et al. 1993, Yenush \& White 1997). The major intracellular substrate for activated IGF-I receptor is insulin receptor substrate-1 (IRS-1), which is also involved in insulin-induced cell responses (Cantley et al. 1991, Sun et al. 1991, Tamemoto et al. 1994). IRS-1 cDNA has been cloned and sequenced (Sun et al. 1991). Phosphorylated IRS-1 is capable of interacting with and activating several SH2-domain-containing proteins, such as the regulatory subunit of phosphatidylinositol-3 kinase (PI3K), growth factor receptor-bound protein 2 (Grb2) (Cantley et al. 1991, LeRoith et al. 1995), protein tyrosine phosphatase (SHP2) (Rocchi et al. 1996, Yenush \& White 
1997) and other intracellular proteins (Jones \& Clemmons 1995). In mice carrying a disrupted IRS-1 gene, insulin and IGF-I stimulate phosphorylation of another docking protein, IRS-2, associated with activation of PI3K (Araki et al. 1994, Tobe et al. 1995). This pathway becomes an alternative, IRS-1-independent pathway in insulin or IGF-I signalling.

In comparison with the insulin receptor, the IGF-I receptor is more effective in mediating cell growth (LeRoith et al. 1995), as demonstrated by the use of antisense oligonucleotides to the IGF-I receptor RNA (Pietrzkowski et al. 1993) or applying cells with targeted disruption of the IGF-I receptor genes ( $\mathrm{Li}$ et al. 1994). IGF-I receptors are essential during development (Liu et al. 1993) and in tumorigenesis (Baserga et al. 1995, Li et al. 1996). In addition, sufficient expression of the IGF-I receptor is required for protection of cell death from apoptosis (Steller 1995, O'Connor et al. 1997), through a signal transduction pathway similar to that involved in the metabolic and mitogenic actions of IGF-I (Párrizas et al. 1997).

IGF-I receptors are present in insulin-secreting cells (Van Schravendijk et al. 1987). Exogenous IGF-I stimulates proliferation of rat islets (Swenne et al. 1987, Hogg et al. 1993), in which IGF-I was shown to have a more potent effect than IGF-II on DNA synthesis (Hogg et al. 1993). A proliferative effect of IGF-I was also demonstrated in the rat insulin-secreting cell line, RINm5F (Dereli et al. 1988). In addition, IGF-I is capable of regulating insulin secretion in insulin-secreting cells. Both stimulatory (Dheen et al. 1996) and inhibitory effects (Van Schravendijk et al. 1990, Zhao et al. 1997) of IGF-I on insulin release have been reported. Therefore, the IGF-I receptor, through interacting with its ligands, has an important role in both growth and hormone secretion in insulin-secreting cells. These cells continuously secrete a large quantity of insulin, which not only binds to the insulin receptor, but also crossreacts with the IGF-I receptor. This raises the question of the nature of the cellular mechanism of the IGF-I receptor that mediates IGF-I actions in insulin-secreting cells. In the present study, we have investigated the role of the IGF-I receptor and underlying molecular mechanisms in the insulin-secreting cell line, RINm5F.

\section{Materials and Methods}

\section{Materials}

Recombinant IGF-I and II were generous gifts from Pharmacia, Stockholm, Sweden. DuPont New England Nuclear (NEN) Products provided [methyl- ${ }^{3} \mathrm{H}$ ] thymidine. Enhanced chemiluminescence (ECL) reagents and $\left[\gamma_{-}{ }^{32} \mathrm{P}\right] \mathrm{ATP}$ were purchased from Amersham (Amersham, UK). Anti-IRS-1 antibody (C-terminal), anti-IRS-2 antibody and mouse 3T3 cell lysate were from
Upstate Biotechnology Inc., NY, USA. Rabbit antiphosphotyrosine $\operatorname{IgG}$ was from Zymed. Genistein and Fura-2/acetoxymethylester (fura-2/AM) were from Sigma, St Louis, USA. Bio-gel P-4 Gel (fine, $65 \pm 20 \mu \mathrm{m}$, wet) and Bio-Rad protein assay reagent were obtained from Bio-Rad Laboratories (Richmond, CA, USA). Culture medium RPMI-1640 and fetal calf serum (FCS) were purchased from Life Technologies (Paisley, UK).

\section{Cell culture}

A rat insulinoma cell line, RINm5F, passage number ranging between 25 and 35 , was maintained in RPMI-1640 tissue culture medium supplemented with $10 \%(\mathrm{v} / \mathrm{v})$ FCS, $100 \mathrm{IU} / \mathrm{ml}$ penicillin and $100 \mu \mathrm{g} / \mathrm{ml}$ streptomycin.

\section{$\left[^{3} H\right]$ Thymidine incorporation}

$\left[{ }^{3} \mathrm{H}\right]$ Thymidine incorporation was performed according to the method of Kato et al. (1994). RINm5F cells were placed in 24 well tissue culture trays $\left(5 \times 10^{4}\right.$ cells/well $)$ in RPMI-1640 medium supplemented with 10\% FCS and grown to $80 \%$ confluence. Cells were washed three times with serum-free medium and kept in serum-free medium for $24 \mathrm{~h}$. Thereafter, the medium was removed and replaced by fresh serum-free medium containing either vehicle or hormones with or without the tyrosine kinase inhibitor, genistein. After an incubation of $18 \mathrm{~h}$, $\left[{ }^{3} \mathrm{H}\right]$ thymidine $(0.5 \mu \mathrm{Ci} /$ well $)$ was added and the incubation was continued for an additional $6 \mathrm{~h}$. At the end of incubation, cells were washed three times in Hepes buffer and lysed with $500 \mu \mathrm{l} 1 \mathrm{M} \mathrm{NaOH} ; 400 \mu \mathrm{l}$ of the lysate was transferred into vials containing scintillation fluid, and radioactivity was determined in a liquid scintillation counter. The remaining $100 \mu \mathrm{l}$ was used for protein determination (Bio-Rad). Results are presented as c.p.m./mg protein.

\section{Receptor binding}

Trypsinized cells were washed three times with ice-cold Hepes buffer containing $10 \mathrm{mM}$ Hepes, $135 \mathrm{mM} \mathrm{NaCl}$, $4.8 \mathrm{mM} \mathrm{KCl}, 1.7 \mathrm{mM} \mathrm{MgSO}_{4}, 2.5 \mathrm{mM} \mathrm{CaCl}_{2}$ and $1.0 \mathrm{mM} \mathrm{NaH} \mathrm{PO}_{4}, \mathrm{pH} 7 \cdot 4$ and resuspended in Hepes buffer-1\% BSA. Cell suspension $\left(100 \mu \mathrm{l}, 5 \times 10^{5}\right.$ cells, per tube) was incubated at $4{ }^{\circ} \mathrm{C}$ overnight with iodine-labelled hormone in the presence or absence of unlabelled polypeptides at a final incubation volume of $300 \mu$ l. The incubation was terminated by aspirating $2 \times 100 \mu \mathrm{l}$ from each assay tube, followed by centrifugation through $250 \mu \mathrm{l}$ of a mixture of phthalic acid esters. The supernatants were eliminated and the tips of the tubes containing cell pellets were excised and counted in a gamma counter. The $100 \mu \mathrm{l}$ remaining in each assay tube was used as reference (Tally et al. 1984). 


\section{Affinity crosslinking}

Affinity crosslinking was performed as described previously (Pilch \& Czech 1979). Trypsinized RINm5F cells were washed with ice-cold $50 \mathrm{mM}$ phosphate buffer, $\mathrm{pH} 7 \cdot 4$. Incubation was carried out in $50 \mathrm{mM}$ phosphate buffer-1\% BSA, pH $7 \cdot 4$, with ${ }^{125}$ I-des(1-3)IGF-I or

${ }^{125}$ I-IGF-II for $40 \mathrm{~min}$ at room temperature in the presence or absence of unlabelled des(1-3)IGF-I $(100 \mathrm{ng} / \mathrm{ml})$ or IGF-II $(100 \mathrm{ng} / \mathrm{ml})$. Affinity crosslinking was carried out on ice for $15 \mathrm{~min}$ using disuccinimidyl suberate (DSS). The reaction was quenched with $0.5 \mathrm{M}$ Tris- $\mathrm{HCl}$ and the affinity-labelled cells were solubilized in the sample buffer. After centrifugation, the supernatant was boiled and proteins were separated on SDS-PAGE (10\%) (Laemmli 1970) and visualized by autoradiography.

\section{Immunoprecipitation and western blotting}

Immunoprecipitation of proteins with phosphotyrosine antibody and western blotting using anti-IRS-1 or -2 was performed according to the manufacturer's instructions. Cells were grown in culture dishes to a confluence of $80 \%$. Before the experiment, cells were kept in serum-free RPMI-1640 medium for $24 \mathrm{~h}$. Incubation of cells was carried out in serum-free medium in the presence or absence of $10 \mathrm{nM}$ IGF-I $\left(37^{\circ} \mathrm{C}, 1 \mathrm{~min}\right)$. Cells were washed with ice-cold PBS and solubilized in a lysis buffer containing $50 \mathrm{mM}$ Tris- $\mathrm{HCl}$ (pH 7.4), $150 \mathrm{mM} \mathrm{NaCl}, 1 \mathrm{mM}$ EGTA, $1 \mathrm{mM}$ sodium orthovanadate, $1 \mathrm{mM}$ sodium fluoride, $1 \mu \mathrm{g} / \mathrm{ml}$ aprotinin, $1 \mathrm{mM}$ phenylmethylsulphonyl fluoride, $1 \mu \mathrm{g} / \mathrm{ml}$ leupeptin, $1 \mu \mathrm{g} / \mathrm{ml}$ pepstatin, $0 \cdot 25 \%$ sodium deoxycholate and $1 \%$ Nonidet P-40. The lysate was incubated with anti-phosphotyrosine antibody $(1 \mu \mathrm{g} / \mathrm{ml})$ overnight with gentle shaking. The immunocomplex was precipitated with protein A-Sepharose $\left(4^{\circ} \mathrm{C}, 2 \mathrm{~h}\right)$. The beads were collected by centrifugation and washed with lysis buffer. The immunoprecipitated proteins were solubilized in SDS-PAGE sample buffer. Equal amount of proteins was applied in each lane and separated on SDSPAGE (7\%) under reducing conditions. Mouse 3T3 cell lysate and immunoprecipitated proteins from a $100000 \mathrm{~g}$ supernatant from a rat liver were used as controls. The proteins in the gels were electrotransferred onto nitrocellulose sheets. The sheets were blocked in PBS-3\% non-fat dry milk (PBS-MLK), followed by an overnight incubation with anti-IRS-1 $(0.5 \mu \mathrm{g} / \mathrm{ml})$ or anti-IRS-2 antibodies $(1 \mu \mathrm{g} / \mathrm{ml})$ at $4{ }^{\circ} \mathrm{C}$. The nitrocellulose sheets were intensively washed and incubated with horseradish peroxidase-linked antibodies $(1: 3000)$ for $1.5 \mathrm{~h}$ in PBS-MLK at room temperature. The blots were washed and the immunoreactive proteins were detected with ECL.

\section{Preparation of IGF receptor proteins and protein phosphorylation}

Partial purification of IGF receptor proteins and protein phosphorylation were carried out using the methods described by Shemer et al. (1987). RINm5F cells were

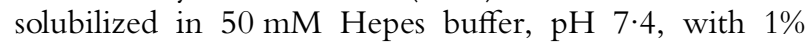
Triton X-100, $100 \mathrm{KIE} / \mathrm{ml}$ aprotinin, $2 \mathrm{mM}$ phenylmethylsulfonyl fluoride, followed by centrifugation at $100000 \boldsymbol{g}$ for $20 \mathrm{~min}$ at $4{ }^{\circ} \mathrm{C}$. The supernatant was allowed to bind to a wheat-germ agglutin (WGA)-agarose in an affinity column (bed volume: $0.5 \mathrm{ml}$ ). The bound proteins were eluted in $0.3 \mathrm{M} \mathrm{N}$-acetyl-D-glucosamine after the column had been washed with 10 bed volumes of $50 \mathrm{mM}$ Hepes buffer-0.1\% Triton X-100, pH 7·4. The partially purified receptor preparation was incubated for $40 \mathrm{~min}$ at room temperature, in the presence or absence of $10 \mathrm{nM}$ IGF-I or $10 \mathrm{nM}$ insulin or IGF-I plus insulin at the same concentrations. Phosphorylation reaction was initiated by the addition of $\left[\gamma_{-}{ }^{32} \mathrm{P}\right] \mathrm{ATP}(15 \mu \mathrm{M})$ to the buffer containing $8 \mathrm{mM} \mathrm{MgCl}_{2}$ and $4 \mathrm{mM} \mathrm{MnCl}_{2}(1 \mathrm{~min}$, $37^{\circ} \mathrm{C}$ ) and terminated by addition of SDS-PAGE sample buffer. The labelled products were separated on SDSPAGE under reducing conditions and visualized by autoradiography.

\section{Insulin release from $\mathrm{RINm} 5 \mathrm{~F}$ cells}

Insulin release from RINm5F cells was determined using a column perifusion system (Kanatsuna et al. 1981). After trypsinization, about $2 \times 10^{5}$ cells were carefully mixed with a small volume of pre-wetted Bio-Gel P-4 and placed on the top of each of two parallel microcolumns (bed volume, $0.5 \mathrm{ml}$ ), pre-packed with the same polyacrylamide beads. Perifusion was performed continuously at $37^{\circ} \mathrm{C}$ with buffer A containing $125 \mathrm{mM} \mathrm{NaCl}, 5.9 \mathrm{mM}$ $\mathrm{KCl}, 1.28 \mathrm{mM} \mathrm{CaCl}, 1.2 \mathrm{mM} \mathrm{MgCl}_{2}, 25 \mathrm{mM}$ Hepes and $0 \cdot 1 \% \mathrm{BSA}, \mathrm{pH} 7 \cdot 4$. The cells were exposed to 50 $\mathrm{ng} / \mathrm{ml} \mathrm{IGF-I} \mathrm{for} 12 \mathrm{~min}$ and depolarized by $25 \mathrm{mM} \mathrm{K}^{+}$at the end of each experiment. The flow rate was $0.2 \mathrm{ml} / \mathrm{min}$ and fractions were collected every $2 \mathrm{~min}$ for insulin radioimmunoassay (Herbert et al. 1965).

\section{Measurement of cytoplasmic free $\mathrm{Ca}^{2+}$ concentration}

Cytoplasmic free $\mathrm{Ca}^{2+}$ concentration $\left(\left[\mathrm{Ca}^{2+}\right]_{\mathrm{i}}\right)$ was measured utilizing a microscope equipped with a photoncounting photometer and connected to a SPEX fluorolog-2 CM1T 111 system, allowing fluorimetry using two excitation wavelengths (Kindmark et al. 1992). RINm5F cells were placed on coverslips in RPMI1640 medium supplemented with $10 \%$ FCS for $24 \mathrm{~h}$. The coverslips with cells were incubated in buffer A containing $1.5 \mu \mathrm{M}$ fura-2-AM for $30 \mathrm{~min}$ at $37^{\circ} \mathrm{C}$. During measurement, the cells were continuously superfused with the buffer $\left(300 \mu \mathrm{l} / \mathrm{min}\right.$ at $\left.37^{\circ} \mathrm{C}\right)$. Measurements were performed on a cell cluster (5-10 cells) at the excitation and emission wavelengths of $340 \mathrm{~nm} / 380 \mathrm{~nm}$ and $510 \mathrm{~nm}$, respectively. Cells were exposed to $50 \mathrm{ng} / \mathrm{ml}$ IGF-I for $4 \mathrm{~min}$ in buffer A containing $3 \mathrm{mM}$ glucose. 


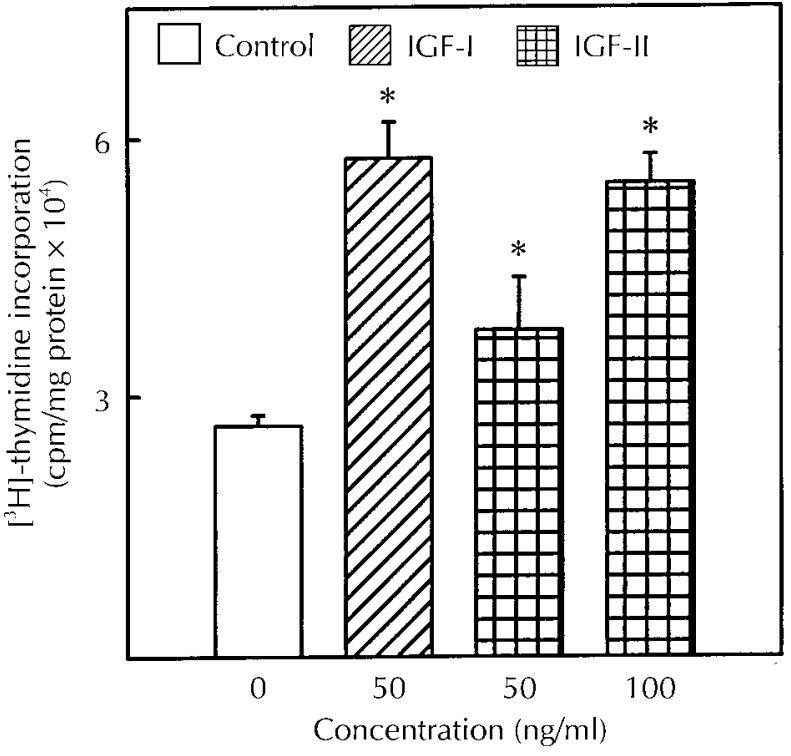

Figure $1\left[{ }^{3} \mathrm{H}\right]$ Thymidine incorporation into RINm5F cells. Quiescent cells were incubated in the absence or presence of IGF-I or IGF-II for $18 \mathrm{~h}$ before addition of $\left[{ }^{3} \mathrm{H}\right]$ thymidine. Mean \pm S.E.M. was derived from a representative experiment, repeated three times, with six determinations. *Statistically significant difference $(P<0 \cdot 05)$ compared with controls.

The results are expressed as the 340/380 fluorescence ratios as described elsewhere (Kindmark et al. 1992).

\section{Results}

Effect of IGFs on $\left.{ }^{3} \mathrm{H}\right]$ thymidine incorporation, $\left[\mathrm{Ca}^{2+}\right]_{i}$ and insulin release

Both IGF-I and IGF-II stimulated thymidine incorporation into RINm5F cells (Fig. 1). At a concentration of $50 \mathrm{ng} / \mathrm{ml} \mathrm{IGF-I,} \mathrm{the}\left[{ }^{3} \mathrm{H}\right]$ thymidine incorporation was doubled. A similar effect was obtained in the presence of $100 \mathrm{ng} / \mathrm{ml}$ IGF-II.

During continuous perifusion in the presence of $3 \mathrm{mM}$ glucose, RINm5F cells failed to respond to IGF-I $(50 \mathrm{ng} / \mathrm{ml})$ with insulin release (Fig. 2). In addition, in the presence of $3 \mathrm{mM}$ glucose, IGF-I did not cause any changes in $\left[\mathrm{Ca}^{2+}\right]_{\mathrm{i}}$ (data not shown).

\section{Presence of IGF receptors}

The presence of cell surface receptors was investigated using ${ }^{125}$ I-des(1-3)IGF-I, human recombinant IGF-II or insulin (Fig. 3A-C). Des(1-3)IGF-I was applied instead of native IGF-I in order to minimize the effects of IGF binding proteins released from the cells; the receptor binding of des(1-3)IGF-I is indistinguishable from that of native IGF-I. The specific binding of ${ }^{125} \mathrm{I}-\operatorname{des}(1-3) \mathrm{IGF}-\mathrm{I}$

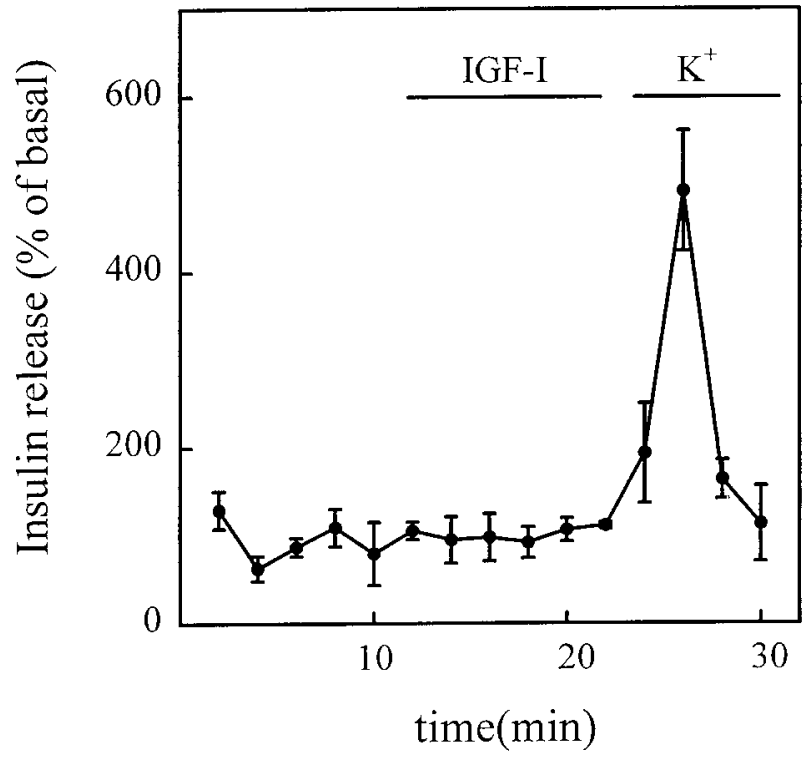

Figure 2 Insulin release from column-perifused RINm5F cells. Perifusion was performed with a buffer containing $1.28 \mathrm{mM} \mathrm{Ca}^{2+}$ and $3 \mathrm{mM}$ glucose. IGF-I $(50 \mathrm{ng} / \mathrm{ml})$ was present for $12 \mathrm{~min}$. Cells were depolarized with $25 \mathrm{mM} \mathrm{K}^{+}$at the end of each experiment as a control. Insulin release is expressed as percentage of basal release, which was derived from the amount of insulin released within the first $10 \mathrm{~min}$. Mean \pm S.D. from three separate experiments.

to RINm5F cells was $18 \%$. Both des(1-3)IGF-I and native IGF-I were shown to be equipotent in the competitive inhibition of the labelled ${ }^{125}$ I-des(1-3)IGF-I binding, indicating that the binding was not attributed to IGF binding proteins. The affinity of IGF-II for the IGF-I receptor on these cells was approximately $6 \%$ in potency compared with IGF-I. Insulin crossreacted less than $0 \cdot 2 \%$. Scatchard analysis of the data obtained from the competitive inhibition study using des(1-3)IGF-I revealed a $K_{\mathrm{d}}$ of $9 \cdot 1 \times 10^{-9} \mathrm{M}$, derived from a two-site model, with approximately $2.7 \times 10^{4}$ high-affinity binding sites per cell. The specific binding for IGF-II was $24 \%$ in the assays using IGF-II as the labelled ligand. Des(1-3)IGF-I or insulin failed to compete with IGF-II for the IGF-II binding. Scatchard analysis of the data revealed a $K_{\mathrm{d}}$ of $2 \times 10^{-10} \mathrm{M}$ with $1 \cdot 8 \times 10^{4}$ IGF-II binding sites per cell. ${ }^{125}$ I-insulin did not display any specific binding to RINm5F cells.

Affinity crosslinking was performed using labelled $\operatorname{des}(1-3)$ IGF-I or IGF-II (Fig. 4). When ${ }^{125} \mathrm{I}-\operatorname{des}(1-3)$ IGF-I was used, a $135 \mathrm{kDa}$ protein band was detected, and the labelled hormone in the gel was displaced by $100 \mathrm{ng} / \mathrm{ml}$ unlabelled des(1-3)IGF-I (A). Affinity crosslinking using ${ }^{125}$ I-IGF-II resulted in a $250 \mathrm{kDa}$ protein (B), competed for by unlabelled IGF-II (100 ng/ml). 

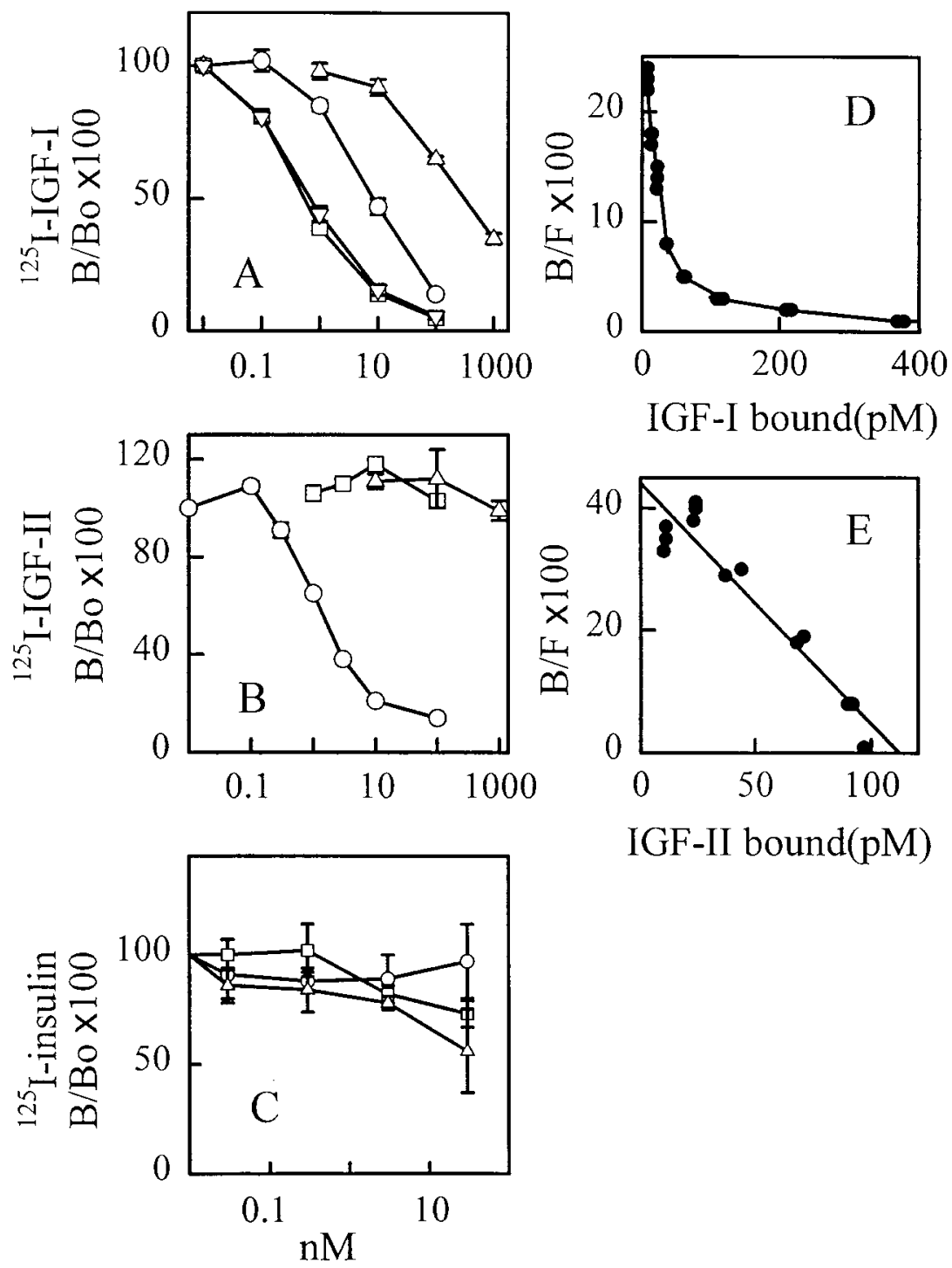

Figure 3 Binding of ${ }^{125}$ I-labelled des(1-3)IGF-I (A), IGF-II (B), or insulin (C) to RINm5F cells in the presence or absence of increasing concentrations of unlabelled des(1-3)IGF-I $(\nabla)$, IGF-I $(\square)$, IGF-II $(\bigcirc)$, or insulin $(\triangle)$. Incubations were performed at $4{ }^{\circ} \mathrm{C}$, overnight. Mean \pm S.D. derived from a representative experiment, repeated three times, with three determinations. D and E, Scatchard analyses derived from binding of ${ }^{125} \mathrm{I}$-des(1-3) IGF-I or ${ }^{125}$ I-IGF-II to the cells respectively.

Effects of genistein on IGF-I-induced receptor phosphorylation and $\left.{ }^{3} H\right]$ thymidine incorporation

In order to characterize the functional IGF-I receptor in RINm5F cells, protein phosphorylation was performed using a WGA-purified fraction of solubilized plasma membranes. As shown in Fig. 5A, two phospho-labelled protein bands with molecular masses of $97 \mathrm{kDa}$ and $93 \mathrm{kDa}$ were stimulated by IGF-I or insulin. Densitometric analysis of the protein bands, using a scanner connected to a computer, revealed a twofold increase in phosphorylation of the two proteins stimulated by IGF-I. Combination of IGF-I with insulin did not show any additional effect.

The IGF-I-induced protein phosphorylation was evaluated in the presence of the tyrosine kinase inhibitor, genistein (Fig. 5B). At a concentration of $50 \mathrm{ng} / \mathrm{ml}$, IGF-I caused an increased phosphorylation of the $97 \mathrm{kDa}$ protein, and, to a lesser extent, the $93 \mathrm{kDa}$ protein. Densitometric analysis of the two protein bands revealed an increase of $174 \%$ for the $97 \mathrm{kDa}$ protein and $148 \%$ for the $93 \mathrm{kDa}$ protein. In the presence of $5 \mu \mathrm{M}$ genistein, the 
A

B

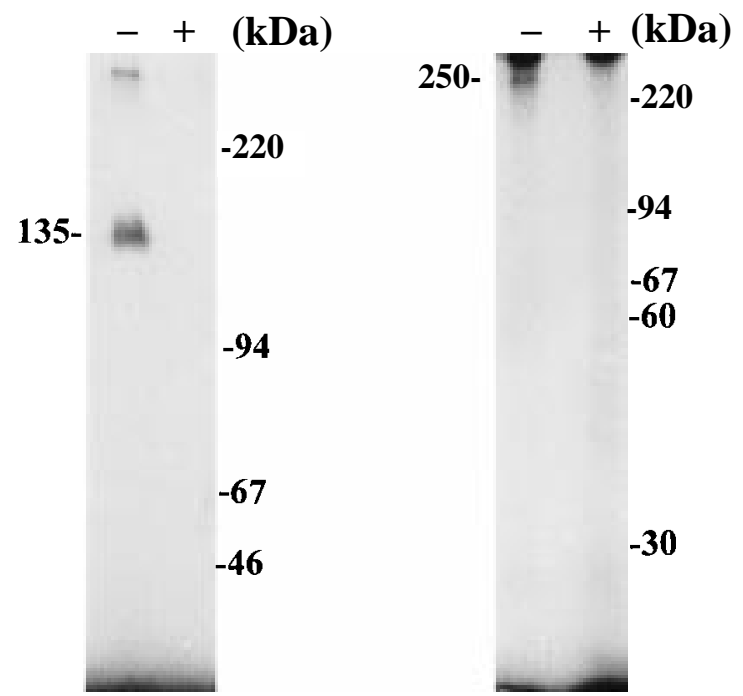

Figure 4 Affinity crosslinking of the cells using ${ }^{125}$ I-des(1-3) IGF-I (A) or ${ }^{125}$ I-IGF-II (B) in the presence $(+)$ or absence $(-)$ of unlabelled des(1-3)IGF-I $(100 \mathrm{ng} / \mathrm{ml})$ or IGF-II $(100 \mathrm{ng} / \mathrm{ml})$ respectively. Trypsinized cells were incubated with indicated hormones for $40 \mathrm{~min}$ at room temperature and crosslinked with DSS. The radiolabelled complex was separated by SDS-PAGE under reducing conditions. Protein molecular mass standards are shown. An experiment representative of two is shown.

A

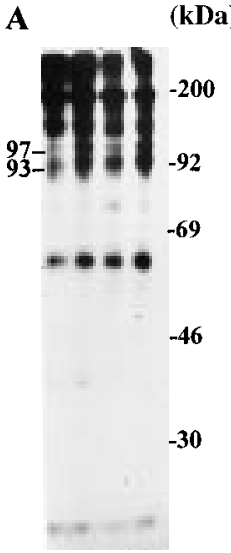

IGF-I $-10-10 \quad n M$

Insulin $-\mathbf{- 1 0 1 0} \mathbf{n M}$
B (kDa)

Figure 5 Phosphorylation of WGA-purified membrane proteins from RINm5F cells. Protein phosphorylation was carried out in the presence or absence of $10 \mathrm{nM}$ IGF-I, $10 \mathrm{nM}$ insulin or in combination (A) and in the presence or absence of IGF-I and genistein (B). The radiolabelled proteins were separated by SDSPAGE under reducing conditions. Protein molecular mass standards are shown. An experiment representative of three is shown.

density of the two phosphorylated bands stimulated by IGF-I was suppressed by $25 \%$. When the concentration of genistein was increased to $10 \mu \mathrm{M}$, the IGF-I stimulated phosphorylation of the two proteins was further suppressed and showed no statistically significant difference in density, compared with controls.

The involvement of tyrosine kinase in the IGF-Iinduced DNA synthesis was investigated in the presence or absence of genistein. Genistein inhibited the IGF-Iinduced $\left[{ }^{3} \mathrm{H}\right]$ thymidine incorporation into RINm5F cells in all concentrations used (Fig. 6). The viability of the cells, as determined by trypan blue exclusion, did not show a significant difference in the presence of genistein in the concentrations used $(1-10 \mu \mathrm{M})$, compared with controls.

\section{IGF-I-stimulated phosphorylation of intracellular proteins}

Immunoprecipitation of proteins from RINm5F cells with antibodies against phosphotyrosine, followed by western blotting using antibodies against rat IRS-1, revealed no tyrosine-phosphorylated IRS-1 in RINm5F cells. Phosphorylated IRS-1 was observed in 3T3 cell lysate and was abundant in the rat liver preparation (Fig. 7A). In contrast, tyrosine-phosphorylated IRS-2 was detected and stimulated by IGF-I in RINm5F cells (Fig. 7B) and no phosphorylated IRS-2 was detected in the rat liver preparation. An additional weak band of an unknown protein, with a molecular mass greater than $200 \mathrm{kDa}$, was found in RINm5F cells on the IRS-2 immunoblot under basal conditions. The later band disappeared after IGF-I stimulation.

\section{Discussion}

The present study shows that both IGF-I and IGF-II/M6P receptors were present in $\mathrm{RINm} 5 \mathrm{~F}$ cells, with dissociation constants similar to those in other cell types (SteelePerkins et al. 1988, Tong et al. 1988). IGF-I and IGF-II stimulated thymidine incorporation into RINm5F cells in a tyrosine kinase-dependent manner. The IGF-Istimulated DNA synthesis in RINm5F cells was associated with phosphorylation of the IGF-I receptor and IRS-2.

In RINm5F cells, activation of the IGF-I receptor did not seem to be associated with the insulin stimulussecretion machinery under basal conditions, as IGF-I had no effect on insulin release and $\left[\mathrm{Ca}^{2+}\right]_{\mathrm{i}}$. However, in rat pancreatic islets, IGF-I has a stimulatory effect on insulin secretion (Dheen et al. 1996). The discrepancy in IGF-I response may be accounted for by a species difference.

IGF-I stimulated phosphorylation of two proteins with molecular masses of $97 \mathrm{kDa}$ and $93 \mathrm{kDa}$ in RINm5F cells, suggesting the presence of two types of $\beta$ subunits of IGF-I receptors, as reported in other cell types (Alexandrides \& Smith 1989, Garofalo \& Rosen 1989, Moxham et al. 1989, Langlois et al. 1995). The two types of $\beta$ subunits might be from the IGF-I receptor and the insulin receptor respectively, forming IGF-I/insulin hybrid receptors, or both types of $\beta$ subunits may have been from the IGF-I receptor 


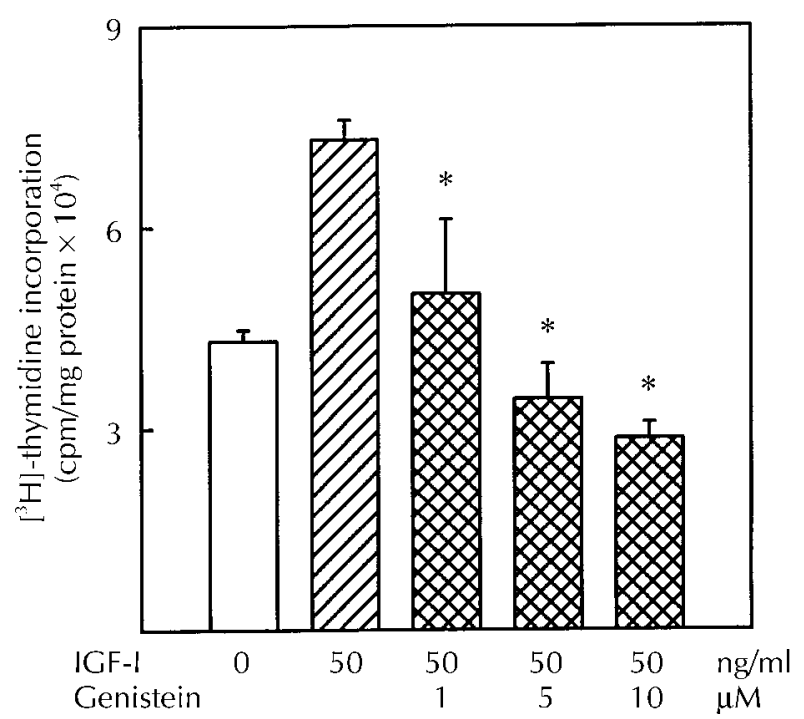

Figure 6 Effect of genistein on incorporation of $\left[{ }^{3} \mathrm{H}\right]$ thymidine into RINm5F cells. Quiescent cells were incubated in the absence (empty bar) or presence of IGF-I (hatched bar) or IGF-I and genistein (cross-hatched bars) for $18 \mathrm{~h}$ before addition of $\left[{ }^{3} \mathrm{H}\right]$ thymidine. Mean \pm S.E.M. derived from a representative experiment with six determinations. *Statistically significant difference $(P<0 \cdot 05)$ in $\left[{ }^{3} \mathrm{H}\right]$ thymidine incorporation into IGF-I-stimulated cells in the presence or absence of genistein. An experiment representative of three is shown.

(Alexandrides \& Smith 1989, Siddle et al. 1994), forming atypical IGF-I receptors in the cells.

IRS-1 is the major substrate for IGF-I and insulin receptors responsible for interaction with cellular effectors, including PI3K (Sun et al. 1991, 1997, Kato et al. 1994). Dominant expression and function of IRS-1 in the cells are believed to contribute to a normal insulin response (Rondinone et al. 1997, Sun et al. 1997). Cells expressing IGF-I receptors but lacking IRS-1 have little or no response to insulin or IGF-I (Chuang et al. 1993), suggesting a key role of IRS-1 in IGF-I and insulin signalling. In RINm5F cells, however, activation of IGF-I receptors did not cause phosphorylation of IRS- 1 . The absence of phosphorylated IRS-1 in these cells cannot be explained by a rapid dephosphorylation of the protein, as phosphorylated IRS-1 remains in the cell longer than does phosphorylated IRS-2 before they are eventually dephosphorylated (Ogihara et al. 1997). In addition, phosphorylated IRS-1 was detected in the mouse $3 \mathrm{~T} 3$ cells and the rat liver extracts in the same experiment, whereas it was absent in RINm5F cells. Hence, IRS-1 does not seem to have an important role in IGF-I signalling in RINm5F cells.

The presence of IRS-2 in RINm5F cells and an enhanced phosphorylation of the protein in response to IGF-I stimulation indicate the involvement of IRS-2 in IGF-I signalling in this cell type. IRS-2 shows both structural and functional similarities with IRS-1 (Sun et al. 1997, Yenush \& White 1997) and is coexpressed with
A

B

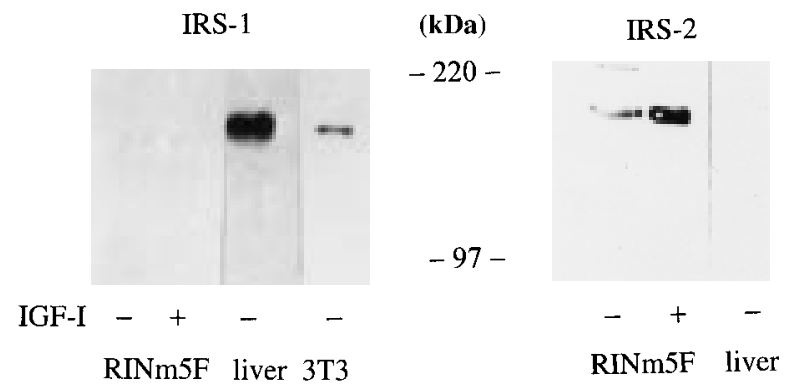

Figure 7 Immunoprecipitation of proteins from RINm5F cells with anti-phosphotyrosine antibodies, followed by western blotting using anti-IRS-1 (A) or anti-IRS-2 (B). Cells were kept in serum-free media for $24 \mathrm{~h}$, followed by incubation at $37^{\circ} \mathrm{C}$ for $1 \mathrm{~min}$ in the presence (+) or absence (-) of $10 \mathrm{nM}$ IGF-I. Proteins were immunoprecipitated. Mouse 3T3 cell lysate and the extraction from rat liver were used as controls. Equal amounts of protein precipitated from RINm5F cells were applied to each lane for IRS-1 or IRS-2 blotting. Four times less protein from the 3T3 cell lysate and twice more protein from the rat liver preparation were applied in the corresponding lanes. Proteins were separated on SDS-PAGE (7\%) under reducing conditions. Proteins in the gels were electrotransferred onto nitrocellulose sheets and the blots incubated with anti-IRS- $1(0.5 \mu \mathrm{g} / \mathrm{ml})$ or anti-IRS-2 $(1 \mu \mathrm{g} / \mathrm{ml})$ for $1 \mathrm{~h}$ at room temperature. The immunoreactive proteins were detected with ECL. An experiment representative of three is shown.

IRS-1 in many cells and tissues (Ogihara et al. 1997, Sun et al. 1997). However, IRS-2 tends to predominate in haematopoietic cells, whereas IRS-1 predominates in adipocytes and muscle cells (Sun et al. 1997). The cellspecific expression of IRS proteins may contribute to cell responses to different stimulators, such as insulin, IGF or cytokines (Sun et al. 1997, Yenush \& White 1997). Although phosphorylated IRS-2 is capable of interacting with and activating PI3K, a greater concentration of insulin is required to achieve a response similar to that obtained through IRS-1 (Rondinone et al. 1997). It has been found that IRS-1 concentrations are reduced, and that IRS-2 is serving as the major docking protein for interaction with PI3K in cells from subjects with noninsulin-dependent diabetes mellitus (Rondinone et al. 1997). This finding indicates an essential role for IRS- 1 in mediating normal insulin actions.

Insulin receptors are present in insulin-secreting cells and the binding capacity of the receptor can be stimulated by certain insulin secretagogues (Jehle et al. 1995). In common with the processes in other types of cells, insulin stimulation results in phosphorylation of the insulin receptor and the association of IRS-1 with PI3K in insulinsecreting cells (Rothenberg et al. 1995). In addition, a possible direct interaction of insulin with the IGF-I receptor in pancreatic $\beta$ cells has been proposed (Bruning et al. 1997). Therefore, it is possible that insulin interacts with both insulin and IGF-I receptors in insulin-secreting 
cells. Signalling through IRS-2 in these cells may be important in decreasing the sensitivity of the cells to insulin, acting through either insulin or IGF-I receptors via autocrine and paracrine mechanisms.

\section{Acknowledgements}

This study was supported by grants from the Swedish Medical Research Council (19X-4224, 03X-09890 19X00034), the Cancer Society in Stockholm (92: 127, 93: 147).

\section{References}

Alexandrides TK \& Smith RJ 1989 A novel fetal insulin-like growth factor (IGF) I receptor. Mechanism for increased IGF-I- and insulin-stimulated tyrosine kinase activity in fetal muscle. Journal of Biological Chemistry 264 12922-12930.

Araki E, Lipes MA, Patti M-E, Brüning JC, Haag B III, Johnson RS \& Kahn CR 1994 Alternative pathway of insulin signalling in mice with targeted disruption of the IRS-1 gene. Nature 372 186-190.

Baserga R 1995 The insulin-like growth factor I receptor: a key to tumour growth? Cancer Research 55 249-252.

Bruning JC, Winnay J, Bonner-Weir S, Taylor SI, Accili D \& Kahn CR 1997 Development of a novel polygenic model of NIDDM in mice heterozygous for IR and IRS-1 null alleles. Cell $\mathbf{8 8}$ 561-572.

Cantley LC, Auger KR, Carpenter C, Duckworth B, Graziani A, Kapeller R \& Soltoff S 1991 Oncogenes and signal transduction. Cell 64 281-302.

Chuang L-M, Myers MG Jr, Backer JM, Shoelson SE, White MF, Birnbaum MJ \& Kahn CR 1993 Insulin-stimulated oocyte maturation requires insulin receptor substrate 1 and interaction with the SH2 domains of phosphatidylinositol 3-kinase. Molecular and Cellular Biology 13 6653-6660.

Dereli S, Fleck H, Sieradzki J \& Schatz H 1988 Influence of growth factors on an insulin-producing cell line (RINm5F). Acta Endocrinologica 118 559-565.

Dheen ST, Rajkumar K \& Murphy LJ 1996 Effects of insulin-like growth factors (IGF) on pancreatic islet function in IGF binding protein-1 transgenic mice. Diabetologia 39 1249-1254.

Garofalo RS \& Rosen OM 1989 Insulin and insulin-like growth factor 1 (IGF-1) receptors during central nervous system development: expression of two immunologically distinct IGF-1 receptor beta subunits. Molecular and Cellular Biology 9 2806-2817.

Herbert V, Lau KS, Gottlieb CW \& Bleicher SJ 1965 Coated charcoal immunoassay of insulin. Journal of Clinical Endocrinology and Metabolism 25 1375-1384.

Hogg J, Han VK, Clemmons DR \& Hill DJ 1993 Interactions of nutrients, insulin-like growth factors (IGFs) and IGF-binding proteins in the regulation of DNA synthesis by isolated fetal rat islets of Langerhans. Journal of Endocrinology 138 401-412.

Jehle PM, Jehle D, Fussganger RD \& Adler G 1995 Effects of glucagon-like peptide-1 (GLP-1) in RINm5F insulinoma cells. Stimulation of insulin secretion, insulin content, and insulin receptor binding. Experimental and Clinical Endocrinology and Diabetes 103 (Suppl 2) 31-36.

Jones JI \& Clemmons DR 1995 Insulin-like growth factors and their binding proteins: biological actions. Endocrine Reviews 16 3-34.

Kanatsuna T, Lernmark ^̊, Rubenstein AH \& Steiner DF 1981 Block in insulin release from column-perifused pancreatic beta-cells induced by islet cell surface antibodies and complement. Diabetes $\mathbf{3 0}$ 231-234.

Kasuya J, Paz IB, Maddux BA, Goldfine ID, Hefta SA \& FujitaYamaguchi Y 1993 Characterization of human placental insulin-like growth factor-I/insulin hybrid receptors by protein microsequencing and purification. Biochemistry 32 13531-13536.

Kato H, Faria TN, Stannard B, Roberts CT Jr \& LeRoith D 1994 Essential role of tyrosine residues 1131, 1135, and 1136 of the insulin-like growth factor-I (IGF-I) receptor in IGF-I action. Molecular Endocrinology 8 40-50.

Kindmark H, Köhler M, Efendic S, Rorsman P, Larsson O \& Berggren P-O 1992 Protein kinase C activity affects glucoseinduced oscillations in cytoplasmic free $\mathrm{Ca}^{2+}$ in the pancreatic B-cell. FEBS Letters 303 85-90.

Laemmli UK 1970 Cleavage of structural proteins during the assembly of the head of bacteriophage T4. Nature 227 680-685.

Langlois WJ, Sasaoka T, Yip CC \& Olefsky JM 1995 Functional characterization of hybrid receptors composed of a truncated insulin receptor and wild type insulin-like growth factor 1 or insulin receptors. Endocrinology 136 1978-1986.

LeRoith D, Werner H, Beitner-Johnson D \& Roberts CT Jr 1995 Molecular and cellular aspects of the insulin-like growth factor I receptor. Endocrine Reviews 16 143-163.

Li S, Ferber A, Miura M \& Baserga R 1994 Mitogenicity and transforming activity of the insulin-like growth factor-I receptor with mutations in the tyrosine kinase domain. Journal of Biological Chemistry 269 32558-32564.

Li S, Resnicoff M \& Baserga R 1996 Effect of mutations at serines $1280-1283$ on the mitogenic and transforming activities of the insulin-like growth factor I receptor. Journal of Biological Chemistry 271 12254-12260.

Liu JP, Baker J, Perkins AS, Robertson EJ \& Efstratiadis A 1993 Mice carrying null mutations of the genes encoding insulin-like growth factor I (IGF-1) and type 1 IGF receptor (IGF-1r). Cell 75 $59-72$.

Moxham CP, Duronio V \& Jacobs S 1989 Insulin-like growth factor I receptor beta-subunit heterogeneity. Evidence for hybrid tetramers composed of insulin-like growth factor I and insulin receptor heterodimers. Journal of Biological Chemistry 264 13238-13244.

O'Connor R, Kauffmann-Zeh A, Liu Y, Lehar S, Evan GI, Baserga R \& Blattler WA 1997 Identification of domains of the insulin-like growth factor I receptor that are required for protection from apoptosis. Molecular and Cellular Biology 17 427-435.

Ogihara T, Shin BC, Anai M, Katagiri H, Inukai K, Funaki M, Fukushima Y, Ishihara H, Takata K, Kikuchi M, Yazaki Y, Oka Y \& Asano T 1997 Insulin receptor substrate (IRS)-2 is dephosphorylated more rapidly than IRS-1 via its association with phosphatidylinositol 3-kinase in skeletal muscle cells. Journal of Biological Chemistry 272 12868-12873.

Oh Y, Muller HL, Neely EK, Lamson G \& Rosenfeld RG 1993 New concepts in insulin-like growth factor receptor physiology. Growth Regulation 3 113-123.

Párrizas M, Saltiel AR \& LeRoith D 1997 Insulin-like growth factor I inhibits apoptosis using the phosphatidylinositol 3 '-kinase and mitogen-activated protein kinase pathways. Journal of Biological Chemistry 272 154-161.

Pietrzkowski Z, Mulholland G, Gomella L, Jameson BA, Wernicke D \& Baserga R 1993 Inhibition of growth of prostatic cancer cell lines by peptide analogues of insulin-like growth factor 1 . Cancer Research 53 1102-1106.

Pilch PF \& Czech MP 1979 Interaction of cross-linking agents with the insulin effector system of isolated fat cells. Journal of Biological Chemistry 254 3375-3381.

Rocchi S, Tartare-Deckert S, Sawka-Verhelle D, Gamha A \& van Obberghen E 1996 Interaction of SH2-containing protein tyrosine phosphatase 2 with the insulin receptor and the insulin-like growth factor-1 receptor: studies of the domains involved using the yeast two-hybrid system. Endocrinology 137 4944-4952. 
Rondinone CM, Wang LM, Lonnroth P, Wesslau C, Pierce JH \& Smith U 1997 Insulin receptor substrate (IRS) 1 is reduced and IRS-2 is the main docking protein for phosphatidylinositol 3-kinase in adipocytes from subjects with non-insulin-dependent diabetes mellitus. Proceedings of the National Academy of Sciences of the USA 94 4171-4175.

Roth RA \& Kiess W 1994 Insulin-like growth factor receptors: recent developments and new methodologies. Growth Regulation 4 (Suppl 1) 31-38.

Rothenberg PL, Willison LD, Simon J \& Wolf BA 1995 Glucoseinduced insulin receptor tyrosine phosphorylation in insulinsecreting beta-cells. Diabetes 44 802-809.

Shemer J, Raizada MK, Masters BA, Ota A \& LeRoith D 1987 Insulin-like growth factor I receptors in neuronal and glial cells. Characterization and biological effects in primary culture. Journal of Biological Chemistry 262 7693-7699.

Siddle K, Soos MA, Field CE \& Navé BT 1994 Hybrid and atypical insulin/insulin-like growth factor 1 receptors. Hormone Research $\mathbf{4 1}$ (suppl 2) 56-65.

Steele-Perkins G, Turner J, Edman JC, Hari J, Pierce SB, Stover C, Rutter WJ \& Roth RA 1988 Expression and characterization of a functional human insulin-like growth factor I receptor. Journal of Biological Chemistry 263 11486-11492.

Steller H 1995 Mechanisms and genes of cellular suicide. Science $\mathbf{2 6 7}$ 1445-1449.

Sun XJ, Rothenberg P, Kahn CR, Backer JM, Araki E, Wilden PA, Cahill DA, Goldstein BJ \& White MF 1991 Structure of the insulin receptor substrate IRS-1 defines a unique signal transduction protein. Nature 352 73-77.

Sun XJ, Pons S, Wang LM, Zhang Y, Yenush L, Burks D, Myers MG Jr, Glasheen E, Copeland NG, Jenkins NA, Pierce JH \& White MF 1997 The IRS-2 gene on murine chromosome 8 encodes a unique signaling adapter for insulin and cytokine action. Molecular Endocrinology 11 251-262.

Swenne I, Hill DJ, Strain AJ \& Milner RD 1987 Growth hormone regulation of somatomedin $\mathrm{C} /$ insulin-like growth factor I production and DNA replication in fetal rat islets in tissue culture. Diabetes 36 288-294.
Tally M, Tang XZ, Enberg G \& Hall K 1984 The binding of insulin-like growth factor II to the erythroleukemia cell-line K-562. Bioscience Reports 4 1071-1077.

Tamemoto H, Kadowaki T, Tobe K, Yagi T, Sakura H, Hayakawa T, Terauchi Y, Ueki K, Kaburagi Y, Satoh S, Sekihara H, Yoshioka S, Horikoshi H, Furuta Y, Ikawa Y, Kasuga M, Yazaki Y \& Aizawa S 1994 Insulin resistance and growth retardation in mice lacking insulin receptor substrate-1. Nature 372 182-186.

Tobe K, Tamemoto H, Yamauchi T, Aizawa S, Yazaki Y \& Kadowaki T 1995 Identification of a 190-kDa protein as a novel substrate for the insulin receptor kinase functionally similar to insulin receptor substrate-1. Journal of Biological Chemistry $\mathbf{2 7 0}$ 5698-5701.

Tong PY, Tollefsen SE \& Kornfeld S 1988 The cation-independent mannose 6-phosphate receptor binds insulin-like growth factor II. Journal of Biological Chemistry 263 2585-2588.

Treadway JL, Morrison BD, Goldfine ID \& Pessin JE 1989 Assembly of insulin/insulin-like growth factor-I hybrid receptors in vitro. Journal of Biological Chemistry 264 21450-21453.

Van Schravendijk CF, Foriers A, Van den Brande JL \& Pipeleers DG 1987 Evidence for the presence of type I insulin-like growth factor receptors on rat pancreatic A and B cells. Endocrinology 121 1784-1788.

Van Schravendijk CF, Heylen L, Van den Brande JL \& Pipeleers DG 1990 Direct effect of insulin and insulin-like growth factor-I on the secretory activity of rat pancreatic beta cells. Diabetologia 33 649-653.

Yenush L \& White MF 1997 The IRS-signalling system during insulin and cytokine action. Bioessays 19 491-500.

Zhao AZ, Zhao H, Teague J, Fujimoto W \& Beavo JA 1997 Attenuation of insulin secretion by insulin-like growth factor 1 is mediated through activation of phosphodiesterase 3B. Proceedings of the National Academy of Sciences of the USA 94 3223-3228.

Received 1 July 1997

Revised manuscript received 13 October 1997

Accepted 10 November 1997 